\title{
Correction to: The effects of invasive grass on seedling recruitment of native Atriplex polycarpa (Torr.) S. Watson (Chenopodiaceae) shrubs in the San Joaquin Valley of California
}

\author{
Mitchell L. Coleman • R. Brandon Pratt
}

Published online: 22 March 2019

(C) Springer Nature Switzerland AG 2019

Correction to: Biol Invasions

https://doi.org/10.1007/s10530-019-01944-8

The article The effects of invasive grass on seedling recruitment of native Atriplex polycarpa (Torr.) S. Watson (Chenopodiaceae) shrubs in the San Joaquin Valley of California, written by Mitchell L. Coleman and R. Brandon Pratt, was originally published electronically on the publisher's Internet portal (currently SpringerLink) on 20 February 2019 with open access.
With the author(s)' decision to step back from Open Choice, the copyright of the article changed on 23 March 2019 to (C) Springer Nature Switzerland AG 2019 and the article is forthwith distributed under the terms of copyright.

The original article has been corrected.

Publisher's Note Springer Nature remains neutral with regard to jurisdictional claims in published maps and institutional affiliations.
The original article can be found online at https:// doi.org/10.1007/s10530-019-01944-8.

M. L. Coleman $(\bowtie) \cdot$ R. B. Pratt

Department of Biology, California State University,

Bakersfield, 9001 Stockdale Hwy, Bakersfield, CA 93311,

USA

e-mail: mcoleman10@csub.edu 